\title{
Sprawozdanie z IV Ogólnopolskiego Kongresu Politologii w Lublinie
}

IV Ogólnopolski Kongres Politologii odbył się w dniach 18-20 września 2018 roku w Lublinie. Organizatorami wydarzenia byli: Polskie Towarzystwo Nauk Politycznych, Komitet Nauk Politycznych Polskiej Akademii Nauk. Głównym organizatorem i gospodarzem tegorocznego kongresu był Wydział Politologii UMCS w Lublinie. Przewodniczącą komitetu organizacyjnego była prof. zw. dr hab. Iwona Hofman, zaś przewodniczącym Rady Programowej prof. zw. dr hab. Marek Pietraś. Obrady tegorocznego Kongresu odbywały się pod hasłem Państwo w czasach zmiany. Myśl przewodnia Kongresu była próbą koncentracji na podstawowych, „tradycyjnych” kategoriach politologicznych, jakimi są państwo i władza, ale z uwzględnieniem dynamiki i zmienności, nowych jakościowo cech otoczenia społecznego, w którym państwo funkcjonuje. Chodziło o zmiany na poziomie wnętrza państwa, ale i na poziomie systemu międzynarodowego. W zamyśle organizatorów celem poznawczym Kongresu była analiza sprzężeń między państwem i dynamicznie rozwijającym się otoczeniem. $\mathrm{Z}$ jednej strony przedmiotem analizy była zmiana wewnętrznych i zewnętrznych warunków funkcjonowania państwa i sprawowania władzy, a z drugiej adaptacja państwa na poziomie jego wnętrza i systemu międzynarodowego - lub jej brak - do dynamicznie rozwijającej się rzeczywistości.

W pierwszym dniu Kongresu 18 września przedstawiciele władz dziekańskich oficjalnie przywitali wszystkich uczestników. Gościem specjalnym, głównym mówcą Kongresu był prof. Stefano Guzzini. Po wystąpieniu gościa specjalnego rozpoczęła się I sesja plenarna pod hasłem Państwo w czasach zmiany. Moderatorami sesji byli: prof. dr hab. Marek Pietraś (UMCS) i prof. dr hab. Andrzej Mania (UJ). Uczestnikami I sesji plenarnej byli: prof. dr hab. Teresa Łoś-Nowak z tematem referatu „Uwarunkowania zmiany środowiska państwa”, prof. dr hab. Andrzej Antoszewski z referatem „Państwo jako podmiot polityki wewnętrznej w czasach zmiany”, prof. dr hab. Roman Kuźniar z referatem "Państwo jako podmiot stosunków międzynarodowych w czasach zmiany”, prof. Zbigniew Czachór z referatem „Państwo członkowskie Unii Europejskiej w czasach zmiany”, prof. Alicja Stępień-Kuczyńska z referatem „Państwa Europy Środkowej 
i Wschodniej w czasach zmiany”, Prof. Jarosław Hrycak z referatem „Ukraina jako państwo w czasach zmiany”, Prof. Mirosław Karwat z referatem „Badanie państwa w czasach zmiany".

Po pierwszej części obrad plenarnych o godzinie 15:15 nastąpiło oficjalne otwarcie Kongresu. Dziekan Wydziału Politologii - Przewodnicząca Komitetu Organizacyjnego powitała gości specjalnych przybyłych na ceremonię otwarcia. W uroczystości uczestniczył Wicepremier, Minister Nauki i Szkolnictwa Wyższego dr Jarosław Gowin. Minister w wystąpieniu odniósł się do nowej Ustawy o szkolnictwie wyższym. W otwarciu uczestniczyli również: Jego Magnificencja prof. Stanisław Michałowski - Rektor UMCS, prof. Arkadiusz Żukowski - Prezes Zarządu Głównego Polskiego Towarzystwa Nauk Politycznych, prof. Tadeusz Wallas - Przewodniczący Komitetu Nauk Politycznych Polskiej Akademii Nauk, dr Krzysztof Żuk - Prezydent miasta Lublina, prof. Ilter Turan - President of International Political Science Association. Po oficjalnym otwarciu Kongresu Dyrektor Centrum Europy Wschodniej UMCS prof. dr hab. Walenty Baluk wręczył prof. dr. hab. Zacharowi Szybiece z Centrum Badań nad Diasporą Żydowską z Uniwersytetu w Tel Awiwie Medal św. Cyryla i Metodego. Drugą sesję plenarną poświęcono formowaniu się państwowości polskiej. Sesję zatytułowano 100 lat państwowości Polski Odrodzonej. Bilans historycznego doświadczenia. Sesję prowadził Jego Magnificencja Rektor prof. Stanisław Michałowski wraz z prof. Ewą Maj (UMCS). Dyskutantami byli: prof. Antoni Dudek, prof. Andrzej Friszke, prof. Andrzej Paczkowski, prof. Waldemar Paruch.

Pierwszy dzień Kongresu zakończył się koncertem w wykonaniu Piotra Selima i uroczystą kolacją.

W drugim dniu Kongresu na Wydziale Ekonomicznym UMCS i na Wydziale Humanistycznym UMCS odbyły się obrady panelowe w 104 panelach otwartych i zamkniętych. Na uwagę zasługuje fakt, że w strukturze paneli znalazły się również panele w językach obcych, głównie w języku rosyjskim i angielskim. Tematyka paneli w językach obcych była zróżnicowana. Poruszano w nich następujące kwestie: Changes in political and social activity in Central and Eastern countries, Contemporary Rusia, Консолидация государств Новой Восточной Европы в аспекте новых вызовов и угроз национальной безопосности, Культурная безопосность в Восточной Европе, Суверенитет vеrsиs конкурентоспособность есть ли выбор угосударства. Dnia 19 września w gmachu Wydziału Politologii odbyła się uroczysta Rada Wydziału Politologii. Uroczyste posiedzenie Rady stanowiło element w obchodach 25. rocznicy powołania do życia Wydziału Politologii UMCS. Drugi dzień Kongresu zakończył się uroczystą kolacją oraz multimedialnym, nocnym pokazem fontann na Placu Litewskim zorganizowanym specjalnie dla uczestników Kongresu.

Dnia 20 września obrady odbyły się na Wydziale Politologii oraz w Instytucie Psychologii. W ostatnim dniu Kongresu obradował Komitet Nauk Politycznych Polskiej Akademii Nauk. W trzecim dniu Kongresu na Wydziale Politologii UMCS gościli przedstawiciele władz państwowych: Minister w Kancelarii Prezydenta RP dr hab. Krzysztof Szczerski, Minister Spraw Zagranicznych RP Jacek Czaputowicz. Na zakoń- 
czenie Kongresu odbył się panel pod tytułem: Polityka zagraniczna Polski - racja stanu, cele, strategia, z udziałem gości specjalnych. Panel zorganizował i prowadził Prof. Waldemar Paruch będący Pełnomocnikiem Premiera RP do spraw Centrum Analiz Strategicznych. W panelu wzięli udział minister Krzysztof Szczerski, minister Jacek Czaputowicz, Wiceprzewodniczący Parlamentu Europejskiego Zdzisław Krasnodębski, prof. Tomasz Grosse z Uniwersytetu Warszawskiego i Europejskiego Centrum Natolin, dr hab. Maciej Szymanowski z Katolickiego Uniwersytetu w Budapeszcie. Na zakończenie Kongresu Dziekan Wydziału Politologii UMCS prof. dr hab. Iwona Hofman przekazała symbolicznego koziołka przedstawicielom Uniwersytetu Wrocławskiego, gdzie za trzy lata odbędzie się V Kongres Politologii. Po zakończeniu obrad uczestnicy Kongresu uczestniczyli w wycieczce po Lublinie. Wycieczki zorganizowano dla uczestników polskojęzycznych oraz rosyjskojęzycznych. Wycieczkę dla uczestników z Polski poprowadziła dr Elżbieta Pawlak-Hejno, zaś dla uczestników rosyjskojęzycznych mgr Łukasz Jędrzejski.

Kongres honorowym patronatem objął Prezydent RP Andrzej Duda. Ogółem w obradach uczestniczyło 726 uczestników. Reprezentowano 85 ośrodków naukowo-badawczych, w tym 19 z zagranicy. Czterech uczestników reprezentowało instytucje o charakterze państwowym. 